\title{
KMT2D wt Allele
}

National Cancer Institute

\section{Source}

National Cancer Institute. KMT2D wt Allele. NCI Thesaurus. Code C54314.

Human KMT2D wild-type allele is located within 12q12-q14 and is approximately $36 \mathrm{~kb}$ in length. This allele, which encodes histone-lysine $\mathrm{N}$-methyltransferase 2D protein, is involved in an estrogen receptor alpha co-activation complex that is necessary for estrogen-induced gene expression. 